\title{
Correction to: Asymmetric vibrations and chaos in spherical caps under uniform time-varying pressure fields
}

\author{
Giovanni Iarriccio $(\mathbb{D} \cdot$ Antonio Zippo $(\mathbb{D} \cdot$ Francesco Pellicano $\mathbb{1}$
}

Published online: 7 December 2021

(C) Springer Nature B.V. 2021

\section{Correction to: Nonlinear Dyn}

https://doi.org/10.1007/s11071-021-07033-7

The original article was published with erroneous author information. The correct authorship is as it stands in this correction. The original article has been corrected.
Publisher's Note Springer Nature remains neutral with regard to jurisdictional claims in published maps and institutional affiliations.

The original article can be found online at https:// doi.org/10.1007/s11071-021-07033-7.

G. Iarriccio $(\bowtie) \cdot$ A. Zippo · F. Pellicano

University of Modena and Reggio Emilia, 41121 Modena,

Italy

e-mail: giovanni.iarriccio@unimore.it

G. Iarriccio - A. Zippo - F. Pellicano

InterMech MoRe Centre, 41121 Modena, Italy 